\title{
Collective subjects, emancipatory cultures and political transformation
}

\author{
Subjectivity (2011) 4, 1-8. doi:10.1057/sub.2010.29
}

What can today's politics and cultures teach us about subjectivity? Can postdeconstructive theorisations of subjectivity retain or even widen the spaces in which subjects that are no longer metaphysical or humanist might cooperate to construct new emancipatory struggles? Guided by these questions, this special issue explores the ways in which subjectivity is being constituted and contested in the early twenty-first century: it examines radical traditions in the light of their impact on contemporary subject formation and the challenges and opportunities that the theorisation of subjectivity faces in the light of globalised cultural exchanges and crossdisciplinary fertilisations, a dominant neoliberal politics and media, and emerging grassroots movements. Throughout, the question of what it means to be a political subject in the early twenty-first century is explored with reference to a determinedly leftist tradition of anti-capitalism, antiimperialism, anti-racism and anti-sexism.

In an article written in 2004, Fredric Jameson considered the trajectory of theory in recent years and its struggle to coalesce into a 'new and imperfectly explored' phase in which 'the theorizing of collective subjectivities' would take precedent. Jameson suggests that this new phase presents us with some conceptual obstacles, since:

although ... it does not yet theoretically exist, all the words I can find for it are still the old-fashioned and discredited ones, such as the project of a social psychology. One wants to think of formulations (and indeed diagrams) for collectivities that are at least as complex and stimulating as those of Lacan for the individual unconscious. ( Jameson, 2004, pp. 405-406)

The year 2004, of course, also saw the death of Jacques Derrida and thus the passing of the last of the great French thinkers who had dominated 
Anglophone scholarship since the 1970s. Almost 7 years later it seems possible to glimpse the first contours of such theories at the edge of our horizon. Derrida's successors - including Jacques Rancière, Étienne Balibar and Alain Badiou - have all elaborated new conceptions of collective subjectivity in their work. Rejecting any binary confrontation between universalism and particularism Rancière, for instance, locates political subjectivisation as being enacted in-between various subject positions that should be understood in terms of different ideas of multiplicity struggling for equality (Rancière, 1995, p. 65). Meanwhile, Balibar promotes a positive theorisation of the collective political subject, revisiting the Kantian conception of subject as substance. By focusing on the subject as self-determining political actor rather than as logical-ontological category, Balibar aims to overcome the post-Cartesian problematic of an individuated notion of subjectivity (Balibar, 2002; Power, 2007). Meanwhile, Badiou - arguably the most original and influential of these three thinkers has constructed a new philosophy of the subject, which aims explicitly at reversing those emphases on structural determination and the ensuing critique of universalist politics that had defined the diverse group of thinkers often grouped together under the categorisation of 'poststructuralism'. Badiou's subject emerges only when it goes beyond discursive knowledge and claims its own radically subjective truth: a procedure as open to continuous elaboration as it is necessarily collective in its political manifestation (Badiou, 2005).

Working within the emancipatory tradition inaugurated by the works of Spinoza, Rousseau, Kant, Hegel and Marx, these thinkers all place the collective struggles of ordinary people at the centre of their respective philosophical projects (Hewlett, 2007; Hallward, 2008). This spirited reworking of earlier conceptual and political traditions of agency, resistance to capitalism and the formation of 'authentic' articulations of subjectivity through non-alienated labour signal a clear shift away from the dominance of 'poststructuralist' preoccupations with otherness, ethics and intersubjectivity. Although his rereading of Levinas formed part of a radical method of deconstruction (and his own personal political activities spoke of a commitment to anti-imperialism), Derrida always resisted connecting his philosophical work with direct political engagement; even his late 'turn' towards the Marxist tradition in Specters of Marx remains vague about the possibilities of the 'new international'.

Beyond France, the unprecedented critical and popular success of Antonio Negri and Michael Hardt's collaborative project in Empire (2000), Multitude (2004) and Commonwealth (2009) signals a similar concern with theorising contemporary subjectivity through the prism of anti-capitalist political struggle and an interrogation of the relationship between the subject and the workplace. Drawing on Negri's involvement with the Italian Autonomia movement in the 1970s, their project explores a new potential body they name 'multitude', composed of the millions of workers engaged in so-called 'immaterial' modes of labour. These production practices span the increasingly de-regulated and 
flexible production patterns common to the services industries, to the informatisation of an economy relying increasingly on communication technologies, and to the new forms of reproducible and contested property - including vulnerable data banks and computer systems, pirated music and video files and the patenting wars fought over genetic information and modification.

What is striking about Hardt and Negri's project is its equal insistence that subjectivity be understood as inescapably collective, constructed in radical spaces where legal and corporate structures are challenged, and potentially amounting to an alternative understanding of political activity in the twentyfirst century: through social networking that utilises mobile telecommunications and the internet; through the mobilities of migratory labour; and through the collaborative and communicative modes of work inaugurated by globalised corporations themselves. What Jean-Luc Nancy has called the inescapable 'being-with' of our 'singular plural' identities thus not only connotes a renewed concern with the ways in which individual subjects relate - both locally and globally - but also conveys the fundamentally sociable and trans-individual structure of subjectivity (Nancy, 2000, p. 3). Nancy's 'being-with' thus does not posit any putatively individualist or consumerist tendencies. Rather, it may be understood as delineating a model of subjectivity that is always-already and inescapably part of the de-essentialised communities that we inhabit today.

Such a polemical stance against a preceding generation of poststructuralist and postmodernist political and cultural theorists need not be taken to mean the wholesale rejection of such thought. ${ }^{1}$ By working towards a renewed emphasis on collective conceptions of subjectivity, earlier analyses of subject formation, we would argue, are in the process of being returned to the sphere of a direct political engagement with universal emancipation and systemic change. Therefore, our use of the terms 'radical' and 'collective' here denotes a conception of the subject as an agent of trans-individual transformation.

The articles collected in this special issue, then, all interrogate the concrete political and cultural manifestations of contemporary subjectivities, and explore the possibilities (and limitations) of articulating collective politics and cultures. Even where they focus on political philosophy and the intellectual underpinnings of conceptualising subjectivity, our authors utilise theoretical positions in order to advance and examine political engagements, emerging cultural dialogues and the everyday ideological parameters of contemporary subjectivities. In addition, the special issue seeks to examine the potential for the emergence of 'radical' subjectivities from a variety of social and institutional perspectives: from the 'top-down' discursive production of new subjectivities through appeals by government and media elites to cultural memory and the use of historical images and slogans in Britain; to the 'bottom-up' formation of linked Black and Latino subjectivities that develop what traditional Marxist vocabulary terms solidarity, and post-Marxists would call equivalential correspondences, in their shared struggles against racism in Houston, Texas. 
In contrast to much recent work on political subjectivity, which has either focused on its theoretical conceptualisation or has sought to investigate emerging social and political movements, our aim has been to offer a theoretically informed examination of the practical conditions requisite to the realisation of the subject qua political entity and agent of emancipatory action. We believe that this approach to political change and culture has the effect of cutting through disciplinary boundaries and research agendas; and the contributions to this issue by authors working in sociology, politics, and cultural and media studies, would seem to attest to this. It also avoids a tendency that has sometimes hampered the recent rediscovery of subjectivity as the locus of politics: namely its divorce from the actual, and indeed constant, emergence of new subjectivities contesting the practices of power. In return, as the articles by Rebecca Bramall and Ben Pitcher demonstrate so impressively in this issue, any political project needs to begin from an assessment of subjective conditions of possibility as they are enacted semiotically in both cultural and political exchanges.

A number of articles collected here were first presented at a conference at the University of Nottingham in September 2008, sponsored by the British Arts and Humanities Research Council; other articles were invited by the editors from academics working in the United Kingdom and in the United States. Simon Critchley writes in Deleuzian fashion that 'the possibility of the subject is the very possibility of philosophy' (Critchley, 1999, p. 53). We wanted to explore whether this could be reformulated as: 'the possibility of the subject is the very possibility of politics'. To this end, our contributors were asked to consider a number of research questions:

- Is the subject still the locus of a radical left politics?

- What forms of subjectivity are emerging in the twenty-first century?

- What roles can class, gender and ethnicity play for new subjectivities?

- Do changes in social production initiated by economic and cultural globalisation offer a new potential for collective emancipation, or are they only ever complicit with a hegemonic global capitalism?

These questions became particularly pressing over the course of editing this special issue as the current economic and banking crisis began to affect people around the world, putting millions out of work and leading to drastic reductions in public spending and an intensified assault on unionised labour, public pension provision and welfare support. A uniquely visible reaction to these ideologically motivated budget cuts were the protests of workers marching through Athens, Greece, on 5 May 2010. A group of protestors subsequently attempted to storm the parliament building in Syntagma Square, setting a bank on fire - along with other nearby buildings - killing three of the bank's employees.

Although the vast majority of Greek protestors peacefully defended their rights to job and pensions securities, as well as to affordable taxes in the wake of 
what was broadly perceived to be a corrupt government responsible for a spiralling deficit, a small number of protestors enacted extraordinary scenes of violence that promptly dominated television broadcasts around the world.

Such scenes remind us, as Colin Wright argues, of the continuing problem of violence in any radical project pushing for social change. His article 'The violence of the new: Badiou's subtractive destruction and Gandhi's satyagraha' sets out by positing 'an active subject of political transformation whose consistency is collective' (Wright, p. 9) and investigates this subject's relation to the question of violence. Moving away from his earlier Maoism, Badiou's conception of violence leaves behind its ontological foundations and theorises a 'subtractive destruction'. Thus, Badiou rejects a state imagining of violence that extrapolates a tropology of the vulnerable individual onto the wider social body so that disruptions to its smooth functioning are branded as illegitimate. Wright then applies Badiou's renewed theory of violence to Gandhi's promotion of satyagraha, meaning the 'force of truth' or 'force of love', to formulate a notion of logical and symbolical emancipatory 'violence' capable of avoiding the bloodshed that marred India's, and other developing nations', struggle for independence.

Gandhi's understanding of the dual nature of sovereignty, Wright notes, in many ways prefigures the theorisation of 'Empire' and its effects on subjectivity in the work of Antonio Negri and Michael Hardt, which is the subject of Oli Harrison's article 'Negri, self-valorisation and the exploration of the common'. Harrison examines the continuing relevance of Negri's theory of 'self-valorisation' - of building revolutionary subjectivity through workers' opposition to capital and the realisation of their own needs - in his recent collaborative writings with Michael Hardt. The increasing informalisation of labour, the de-unionisation of industrial and public sectors, and the painful erosion of job security across the globe present stark challenges to any theory of revolutionary subjectivity in the twenty-first century. Harrison reconsiders Hardt and Negri's recent theorisation of subjectivity by examining the conceptual development of Negri's theory of self-valorisation during the Italian Autonomia movement of the 1970s, with its politically radical climate of workers' struggles for the self-determination of labour.

By tracing the philosophical current of Negri's thought within this particular socio-historical context, Harrison is able to identify the implications for a reconceived understanding of subjectivity - in terms of unionism and trans-national solidarity - as today's subjects encounter the rhizomatic structures of contemporary globalised capital. Harrison's model of the exploration of 'the common' thus posits a non-essentialist conceptual figure through which real political struggles can be identified as always-already configuring themselves through active enactments of subjectivity. This notion of the 'coming-together' of diverse subjectivities, cooperating through asymmetrical struggles in response to the divisive strategies of power elites, is also interrogated by John D. Márquez in his article, 'The browning of Black politics: Foundational Blackness and new Latino subjectivities'. Increasing Latino immigration not only led to intense debates 
during the 2008 US presidential elections, becoming one of the defining topics of current US politics, but also to widespread reports of Black-Latino violence. Márquez exposes the ideological underpinnings of such media coverage and reveals emerging trans-ethnic Black-Latino subjectivities in Houston, Texas. Analysing ethnographic data, popular media and theories concerning radical power, he demonstrates the ways in which memories of anti-Black racism and Black anti-racism have strongly influenced Latino modes of counter-hegemony. Márquez's article is the first critical investigation into Black-Latino subjectivities in Houston and decisively expands our understanding of the ways in which Black and Latino communities are forging counter-hegemonic strategies that contest racial oppression throughout the United States and transcend racial boundaries through the formation of new political subjectivities.

This question of the crucial role played by cultural memory plays in the formation of politically oriented subjectivities is developed by Rebecca Bramall in 'Dig for victory! Anti-consumerism, austerity and new historical subjectivities'. Examining those austerity-related discourses, which have become popular in the United Kingdom in recent years - in particular the re-emergence of the World War II slogan 'dig for victory' - Bramall explores how the promotion of sustainable living through media and political discourses serves to 'defetishize' commodity histories, evoking memories of food shortages during WW II to constitute new ethical consuming subjects. Following Ernesto Laclau's proposition that a conversion of subjectivity results from persuasion, Bramall argues that the persuasiveness of a culturally invoked slogan like 'dig for victory' lies in its insistence upon historical solutions to contemporary problems, and renders radical ideas, such as operating outside of the capitalist commodity system unthreatening and even appealing. Such historical solutions require an urgent rethinking, argues Bramall, if we are to utilise images and discourses from cultural memory in order to construct radical collective projects and agents amid a global food (and consumption) crisis. Bramall's article thus reconsiders the distinction between 'radical' and 'conservative' histories, between 'hegemonic' and 'counter-hegemonic' narratives, offering a fascinating reading of the discursive articulations of 'radical subjects' and 'radical actions'.

Bramall's enquiry into what it means to be radical in terms of constructing collectively organised subjectivities capable of questioning - if not opposing commodity capitalism, is considered from a different perspective by Ben Pitcher in 'Radical subjects after hegemony'. Pitcher interrogates the contemporary appropriation of anti-racism, feminism, gay rights and green politics, which have come to occupy a hegemonic position within contemporary political discourse in the United Kingdom and beyond. In the process of becoming detached from the participatory social movements that once served as both their progenitors and guarantors, these political projects, argues Pitcher, face the problem of conceptual inertia. Pitcher's article reconfigures contemporary understandings of the so-called demise of radical subject positions within 
twenty-first-century British political life in its insistence that such mainstreaming of formerly progressive political projects should not be seen simply as a political betrayal. Rather, he argues that we should see this mainstreaming as shaping a new terrain of political struggle that cannot be predicated on a nostalgia for radical subjects as we have historically tended to imagine them. In this way, reconfiguring the hegemonic position of those discursive fields championed by the New Left into a trope of success - rather than of failure allows us to move beyond assertions that radical subjectivities are dying out.

Each of these articles, then, offers us new ways of considering what constitute radical, collective subjectivities today. If, as our authors show, subjects seeking to contest the limits of an increasingly narrow political reality are continually in the process of being constituted, our scholarly approaches to these concrete subjects and their diverse modes of subjectivity similarly need to be reconceived in order for us to identify the ways in which they are constructing sites of political alterity against the state and its hegemonic cultural formations. We are beginning to witness the increasingly strident political articulation of such counter-hegemonic subjectivities in the face of severe fiscal austerity across Europe. As we write this introduction in November 2010, the recent strike movement in France against government plans to reduce state pensions saw between 2 and 3 million workers taking to the streets to register their dissent. Meanwhile, the protest against a drastic hike in British higher education tuition fees in London in November saw many thousands of supporters whose peaceful protest was overshadowed by the attack on the Conservative Party's Headquarters. This form of protest represents the feelings of a number of students and activists that violence has become a necessary strategy of dissent, reminding us - as Colin Wright argues - that no politics of change can evade the necessity of a violence that, decisively, must become logical and symbolic rather than ontological or instrumentalised in the Leninist sense.

The recent protest against increased tuition fees in the United Kingdom expresses the urgent necessity of a coming-together for intellectual inquiry and organised dissent. Against the further corporatisation of higher education in Britain by the current centre-right coalition, which looks set to privatise the teaching of the humanities and social sciences and drastically diminish popular access to critical thought, the second decade of the twenty-first century urgently requires the opening up and networking of those 'cracks' within capitalist forms through which, as John Holloway has described, subjectivity can regenerate itself in opposition to the exploitative regimes of capitalism (Holloway, 2010, p. 8). At a time of daunting global challenges - from negotiating climate change and retaining biodiversity, to achieving full employment and universal access to health care and education - the problem remains, as Fredric Jameson noted, to think subjectivities capable of systemic collective transformation. We would add that the challenge is not only of identifying what modes of political transformation are rapidly becoming possible, but also which modalities of 
subject formation are being impeded or eroded, and how such privatisations of collective culture might be resisted.

This intellectual effort would prepare the ground for a reconceptualisation of subjectivity in the second decade of the twenty-first century. Increasingly, the entrenchment of staggering income equalities across the globe is met by the resurgence of old forms of solidarity reconstituted along new subjective and collective trajectories. The challenge, now as ever, is to find a vocabulary through which to expand such counter-hegemonic 'cracks' within contemporary life. We hope this issue responds to that challenge.

\section{Note}

1 The word generation is meant metaphorically rather than literally here and speaks, more properly, of trends within the Anglo-American reception of French philosophy, since Badiou, aged 72, was born only 7 years before Derrida, and 12 years before Deleuze.

\section{References}

Badiou, A. (2005) Being and Event, Translated by O. Feltham. London: Continuum.

Balibar, É. (2002) Three concepts of politics: Emancipation, transformation, civility. In: Politics and the Other Scene, Translated by C. Jones, J. Swenson and C. Turner. London: Verso.

Critchley, S. (1999) Post-deconstructive subjectivity? In: Ethics - Politics - Subjectivity: Essays on Derrida, Levinas and Contemporary French Thought. London: Verso, pp. 51-82.

Hallward, P. (2008) Order and event: On Badiou's logic of worlds. New Left Review 2(53): 97-122.

Hardt, M. and Negri, A. (2000) Empire. Cambridge, MA: Harvard University Press.

Hardt, M. and Negri, A. (2004) Multitude. New York: The Penguin Press.

Hardt, M. and Negri, A. (2009) Commonwealth. Cambridge, MA: The Belknap Press of Harvard University Press.

Hewlett, N. (2007) Badiou, Balibar, Rancière: Rethinking Emancipation. London: Continuum. Holloway, J. (2010) Crack Capitalism. London: Pluto Books.

Jameson, F. (2004) Symptoms of theory or symptoms for theory. Critical Inquiry 30(2): $405-406$.

Nancy, J.-L. (2000) Being Singular Plural, Translaed by R.D. Richardson and A.E. O’Byrne. Stanford, CA: Stanford University Press.

Power, N. (2007) Philosophy's subjects. Parrhesia (3): 55-72.

Rancière, J. (1995) Politics, identification, and subjectivization. In: J. Rajchman (ed.) The Identity in Question. London: Routledge.

Alexander Dunst

Caroline Edwards

Department of English, Faculty of Arts and Human Sciences, University of Surrey, Surrey, UK. E-mail: caroline.edwards@surrey.ac.uk 